\title{
SISTEM INFORMASI GOFOODIES LOMBOK BERBASIS WEBSITE MENGGUNAKAN FRAMEWORK LARAVEL DAN BOOTSTRAP
}

\author{
(Gofoodies Lombok Information System Is Website Based Using The Laravel \\ Framework And Bootstrap)
}

\author{
Muhammad Khaidar Rahman ${ }^{[1]}$, Arik Aranta ${ }^{[1]}$, Raden Bagus Faizal Irany Sidharta ${ }^{[2]}$ \\ ${ }^{[1]}$ Dept Informatics Engineering, Mataram University \\ Jl. Majapahit 62, Mataram, Lombok NTB, INDONESIA \\ ${ }^{[2]}$ GOJEK Indonesia Branch Mataram \\ Jl. Bung Karno 88, Mataram, Lombok NTB, INDONESIA
}

Email: haidarrahmans30@gmail.com, arikaranta@unram.ac.id,ronyfaiza193@gmail.com

\begin{abstract}
Abstrak
Teknologi Informasi saat ini merupakan sebuah kebutuhan dalam melakukan setiap aktivitas di hampir setiap bidang, terutama di dalam sebuah instansi. Tuntutan setiap aktivitas ini yang menjadikan teknologi informasi sebagai bagian terpenting di dalam keberlangsungan kinerja yang sedang dijalankan oleh sebuah instansi. Salah satu bagian dari pengembangan teknologi informasi adalah sistem berbasis website yang pada saat ini telah berkembang pesat. Pada pengabdian masyarakat ini dilakukan pengembangan Sistem Informasi Gofoodies Lombok berbasis website menggunakan Framework Laravel dan Bootstrap, khususnya pada kinerja divisi merchant pada Gojek Indonesia cabang Lombok dalam memberikan kualitas dan konten informasi sehingga nantinya dapat membuat merchant menjadi lebih mudah dalam mendapatkan informasi dan divisi merchant dapat dengan mudah mengelola informasi. Berdasarkan sistem yang dibuat untuk membantu kinerja perusahaan dan didapatkan hasil pengujian dari sistem yang dibuat didapatkan hasil bahwa responden yang merupakan divisi merchant dan marketing setuju dengan sistem yang dibuat.
\end{abstract}

Keywords: Teknologi Informasi, Sistem Informasi, Merchant, Hasil.

\section{Pendahuluan}

\subsection{Latar Belakang}

Teknologi Informasi saat ini merupakan sebuah kebutuhan dalam melakukan setiap aktivitas di hampir setiap bidang, terutama di dalam sebuah instansi. Aplikasi komputer merupakan teknologi yang berkembang pesat pada saat ini, kemajuan teknologi dalam membantu pengolahan data atau informasi yang tersedia dapat berlangsung secara cepat dan efisien serta akurat. Kemajuan aplikasi dapat dilihat dari banyaknya aplikasi yang dapat memudahkan penggunanya dalam membantu pekerjaannya. Salah satu model aplikasi yang sangat berperan penting adalah aplikasi pengolahan data yang sangat bermanfaat dan membantu dalam penyimpanan data, pengubahan data dan pencarian data. Tuntutan setiap aktivias ini yang menjadikan teknologi informasi sebagai bagian terpenting di dalam keberlangsungan kinerja yang sedang dijalankan oleh sebuah instansi. Salah satu hal ini menyebabkan teknologi khususnya aplikasi komputer menjadi pengaruh di dalam sebuah kinerja instansi, baik dalam bentuk sistem informasi berbasis teknologi komputer atau website, teknologi informasi dapat memberikan nilai tambah bagi organisasi sehingga kinerja sebuah organisasi menjadi efisien dan efektif.

Salah satu instansi yang menggunakan dan memanfaatkan teknologi informasi ini adalah PT Gojek Indonesia Cabang Lombok. PT Gojek Indonesia Cabang Lombok merupakan sebuah perusahaan teknologi asal Indonesia yang memberikan layanan di berbagai bidang seperti penjualan makanan, ojek online, pengiriman barang dan berbagai hal lainnya khususnya di wilayah Kota Mataram dan Lombok Barat.

Permasalahan yang terdapat pada PT Gojek Indonesia Cabang Lombok yaitu pengelolaan tentang pemberian dan pengelolaan data informasi kepada merchant masih di handle oleh satu divisi saja dan pendataan untuk daftar menjadi merchant masih harus menggunakan layanan google form dan kebanyakan merchant masih kebingungan terhadap konten informasi yang diberikan sehingga sering manual bertanya melalui aplikasi Whatsapp. Untuk menjawab permasalahan tersebut maka diberikan solusi dengan membuat aplikasi Gofoodies Lombok berbasis website untuk memudahkan penyampaian informasi Gojek terhadap merchant dan pendataan informasi dari merchant bisa lebih teratur. Sistem Informasi Gofoodies Lombok berbasis website dengan menggunakan framework Laravel dan bootstrap yang digunakan untuk mengelola konten informasi terhadap merchant dan menampung 
informasi dari merchant, sehingga nantinya hasil dari pengolahan data tersebut dapat digunakan sebagai bahan untuk meningkatkan loyalitas merchant terhadap Gojek, meningkatkan kualitas Informasi Kepada merchant dan meningkatkan keterikatan antara merchant dengan Gojek.

\subsection{Tujuan dan Manfaat}

a. Tujuan.

Tujuan dari pembuatan sistem informasi gofoodies berbasis website ini adalah : Meningkatkan loyalitas merchant terhadap Gojek, meningkatkan kualitas informasi kepada merchant, meningkatkan keterikatan antara merchant dengan Gojek dan membuat masyarakat mengetahui informasi tentang cara menjadi seorang merchant.

b. Manfaat.

Manfaat dari pembuatan sistem informasi gofoodies berbasis website adalah sebagai berikut:

1. Bagi Instansi

Dapat meningkatkan kualitas informasi kepada merchant, meningkatkan keterikatan antara merchant dengan Gojek, mempermudah penyampaian informasi dari gojek kepada merchant dan meningkatkan loyalitas merchant terhadap gojek.

2. Bagi Pegawai

Dapat memudahkan memantau, mengolah dan memberikan konten informasi yang lebih baik terhadap merchant.

3. Bagi Masyarakat umum

Dapat memudahkan masyarakat dalam mengetahui cara melakukan pendaftaran gofood dan bergabung dengan gojek sebagai merchant.

\section{Tinjauan Pustaka}

\subsection{Sistem Informasi}

Sistem informasi terdiri dari dua kata, yaitu sistem dan informasi. Sistem menurut Fat adalah sebuah himpunan "benda" nyata atau abstrak ( $a$ set of thing) yang terdiri dari bagian-bagian atau komponen-komponen yang saling berkaitan, berhubungan, berketergantungan, saling mendukung, yang secara keseluruhan bersatu dalam satu kesatuan (Unity) untuk mencapai suatu tujuan tertentu secara efisien dan efektif. Menurut Davis, G.B, sistem secara fisik adalah kumpulan dari elemen-elemen yang beroperasi bersama-sama untuk menyelesaikan suatu sasaran [2].

\subsection{Website}

Website adalah kumpulan halaman-halaman yang digunakan untuk mempublikasikan informasi berupa teks, gambar dan program multimedia lainnya berupa animasi (gambar gerak, tulisan gerak), suara dan atau gabungan dari semuanya itu baik yang bersifat statis maupun dinamis yang membentuk satu rangkaian bangunan yang saling terkait antara satu page dengan page yang lain yang sering disebut sebagai hyperlink [3].

\subsection{Basis Data}

Basis data merupakan kumpulan beberapa data yang disusun dalam suatu tabel yang saling berelasi ataupun tidak berelasi dan tersimpan di suatu media. Keberadaan sistem basis data di dalam sistem informasi adalah mutlak karena suatu sistem informasi tidak akan terealisasi tanpa adanya keterlibatan sistem basis data [3].

\subsection{ERD}

Entity-Relationship Model adalah salah satu dari model data. Pemodelan data (data modeling) adalah teknik untuk mengorganisasikan dan mendokumentasikan data dari suatu sistem. Entity-Relationship Model menggunakan Entity-Retationship Diagram (ERD) untuk mengorganisasikan dan mendokumentasikan data tersebut. Untuk memahami ERD, perlu dipahami terlebih dulu tentang konsep entities, attributes, primary key, foreign key, relationshrps, dan cardinality [3].

\subsection{Framework Laravel}

Laravel adalah sebuah framework PHP yang dirilis dibawah lisensi MIT, dibangun dengan konsep MVC (Model View Controller). Laravel adalah pengembangan website berbasis MVC yang ditulis dalam PHP yang dirancang untuk meningkatkan kualitas perangkat lunak dengan mengurangi biaya pengembangan awal dan biaya pemeliharaan, dan untuk meningkatkan pengalaman bekerja dengan aplikasi dengan menyediakan sintaks yang ekspresif, jelas dan menghemat waktu. MVC adalah teknik atau konsep yang memisahkan komponen utama menjadi tiga komponen yaitu Model, View dan Controller.

\subsection{Framework Bootstrap}


Bootstrap adalah paket aplikasi siap pakai untuk membuat front-end sebuah website. Bisa dikatakan, bootstrap adalah template desain web dengan fitur plus. Bootstrap diciptakan untuk mempermudah proses desain web bagi berbagai tingkat pengguna, mulai dari level pemula hingga yang sudah berpengalaman[3].

\subsection{Use Case Diagram}

Use case diagram merupakan diagram yang menggambarkan kelakuan (behavior) sistem informasi yang dibuat. Use case diagram digunakan untuk mengetahui fungsi apa saja yang terdapat di dalam sistem dan siapa saja yang berhak melakukan fungsi-fungsi tersebutArsip dan pegawai Biro Gubernuran pada system [4].

\subsection{Activity Diagram}

Activity diagram menggambarkan alur kerja sebuah urutan aktivitas pada suatu proses [4].

\subsection{Sequence Diagram}

Sequence diagram menggambarkan interaksi antar objek di dalam dan di sekitar sistem (termasuk pengguna, display, dan sebagainya) berupa message yang digambarkan terhadap waktu [4].

\subsection{Web Server}

Web merupakan salah satu teknologi informasi yang menghubungkan data dari banyak sumber dan layanan yang bermacam-macam di internet. Sedangkan web server merupakan server yang digunakan untuk menyimpan halaman-halaman dari sebuah website [5].

\subsection{Visual Studio Code}

Visual Studio Code adalah sebuah software aplikasi/editor text untuk bahasa pemrograman multi bahasa termasuk pemrograman PHP dan Javascript yang akan digunakan untuk mengembangkan sistem, Visual Studio Code mendukung banyak bahasa pemrograman dan bahasa markup serta fungsinya dapat ditambah dengan plugin.

\subsection{MySQL}

MySQL merupakan salah satu jenis basis data yang pada umumnya sering digunakan dan sangat terkenal. Basis data yang tersimpan dalam basis data MySQL terdiri dari sejumlah tabel-tabel yang memiliki sejumlah baris dan sejumlah kolom [5].

\section{Metode Pengabdian masyarakat}

\subsection{Metode Perancangan Sistem}

Pengembangan sebuah perangkat lunak pada umumnya dilakukan dengan menggunakan kaidah software engineering (rekayasa perangkat lunak). Pada pengabdian masyarakat ini dilakukan pembuatan perangkat lunak dengan menggunakan model waterfall yang terdapat pada gambar 1. Model waterfall atau yang sering disebut dengan model classic life cycle menunjukan pengembangan perangkat lunak secara terstruktur dan sistematis dimulai dari tahap analisis kebutuhan sistem lalu menuju ke tahap analisis, desain, coding, testing/verification, dan maintence [3].

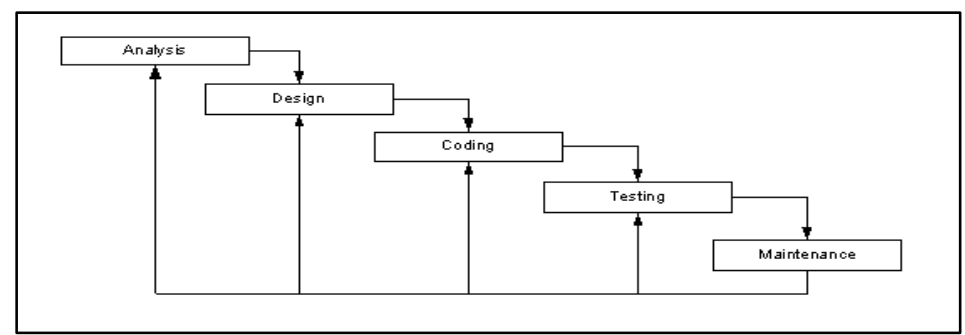

Gambar 1. Metode Penelitian Waterfall

\subsection{Desain Sistem}

Pada sistem sistem informasi gofoodies berbasis website ini terdapat 4 (empat) diagram dalam desain sistem yaitu Use Case Diagram, Activity Diagram, Sequence Diagram dan Entity Relationship Diagram, berikut sebagian penjelasannya:

\subsubsection{Use Case Diagram}

Berikut ini merupakan Use Case Diagram sistem informasi gofoodies berbasis website yang ditunjukan pada gambar 2. 


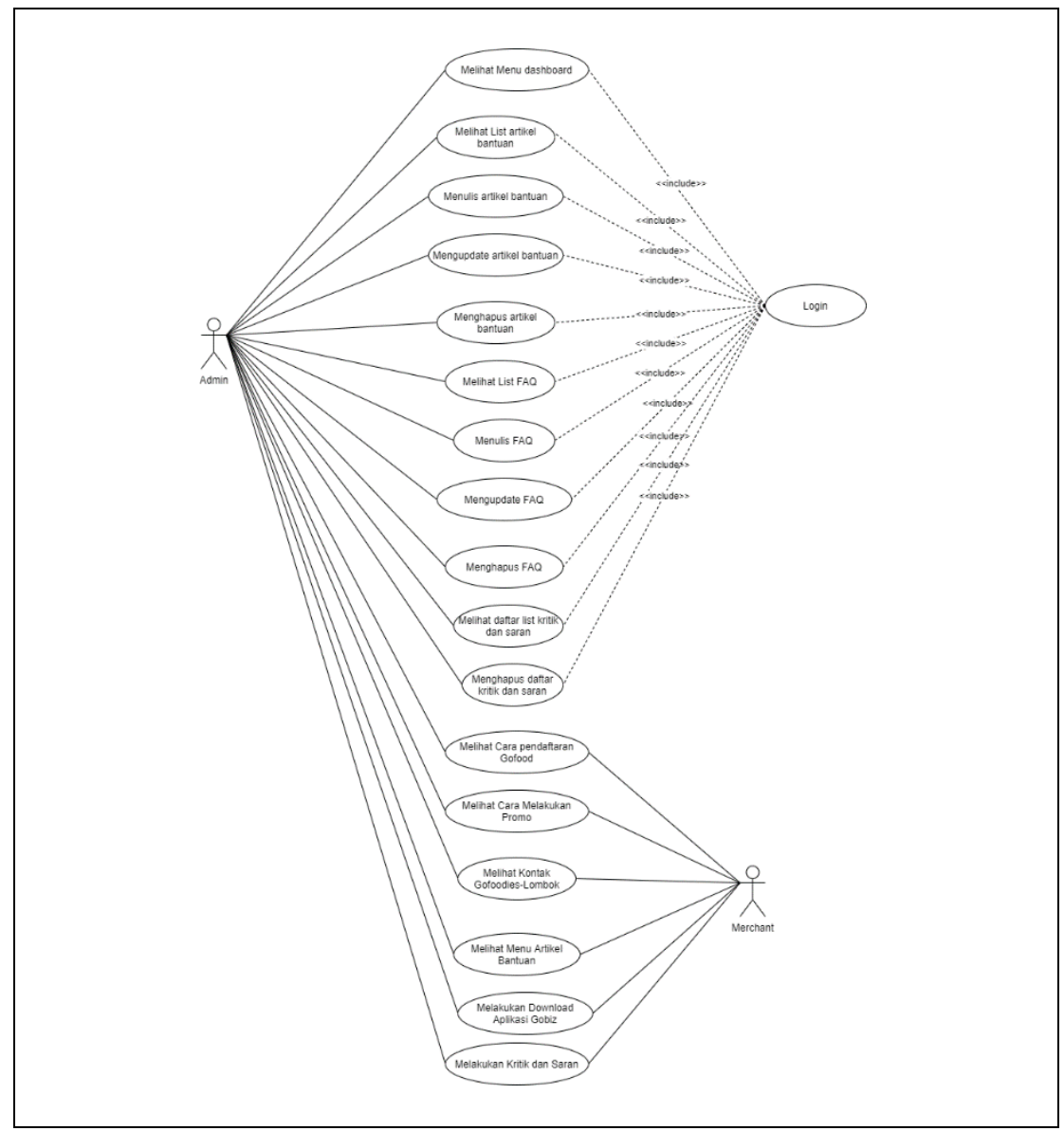

Gambar 2. Use case diagram

Gambar 2 merupakan usecase diagram pada sistem informasi gofoodies berbasis website. User dari sistem ini adalah:

1. Merchant, berfungsi sebagai user merchant yang dapat melakukan:
a. Melihat Cara pendaftaran Gofood
b. Melihat Cara Melakukan Promo
c. Melihat Kontak Gofoodies Lombok
d. Melihat Menu FAQ bantuan
e. Melihat Menu Artikel Bantuan
f. Melakukan Download Aplikasi Gobiz
g. Melakukan Kritik dan Saran

2. Admin, berfungsi sebagai admin yang dapat melakukan:
a. Login sebagai admin
b. Melakukan semua yang bisa dilakukan oleh merchant
c. Melihat Menu dashboard
d. Melihat list artikel bantuan
e. Menulis artikel bantuan
f. Mengupdate artikel bantuan
g. Menghapus artikel bantuan
h. Melihat list FAQ
i. Menulis FAQ
j. Mengupdate FAQ
k. Menghapus FAQ
1. Melihat daftar list kritik dan saran
m. menghapus daftar kritik dan saran
n. Logout dari system 


\subsubsection{Activity Diagram}

Berikut merupakan Activity Diagram dari sistem informasi gofoodies berbasis website.

a. Proses melihat daftar gofood

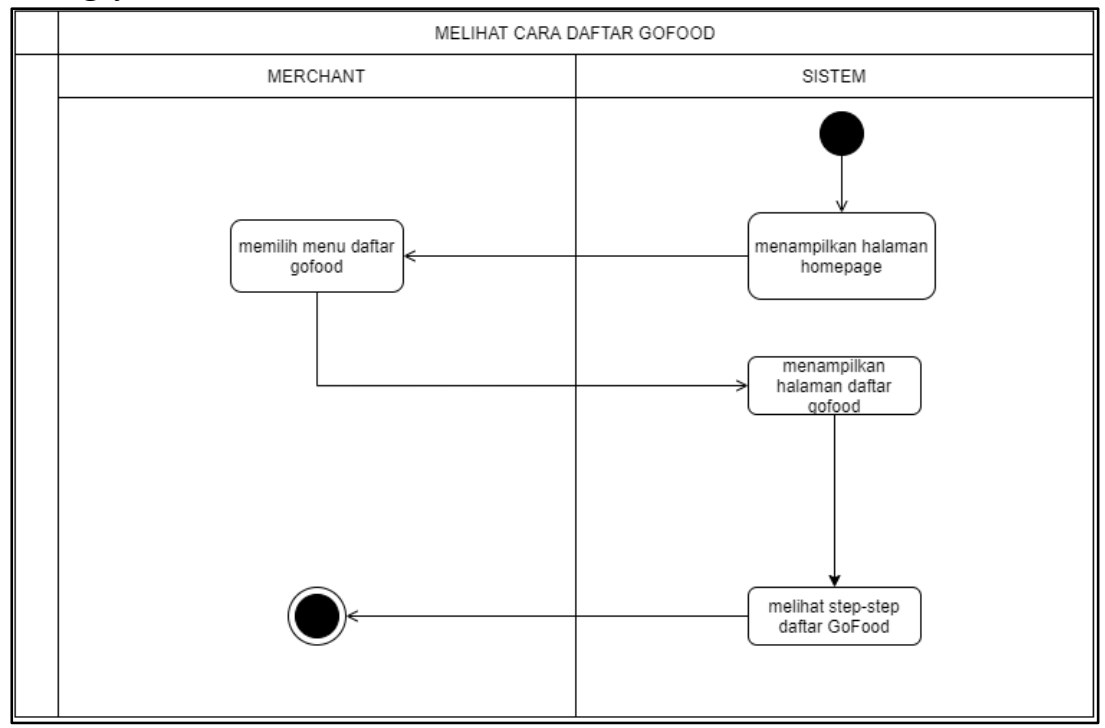

Gambar 3. Activity diagram melihat daftar gofood

Gambar 3 merupakan activity diagram dari proses melihat daftar gofood sebagai merchant yang dimulai dari sistem menampilkan halaman homepage. Kemudian pengguna memilih menu navigasi daftar gofood. Setelah itu, sistem mengarahkan untuk menampilkan halaman daftar gofood.

b. Proses melihat cara promo

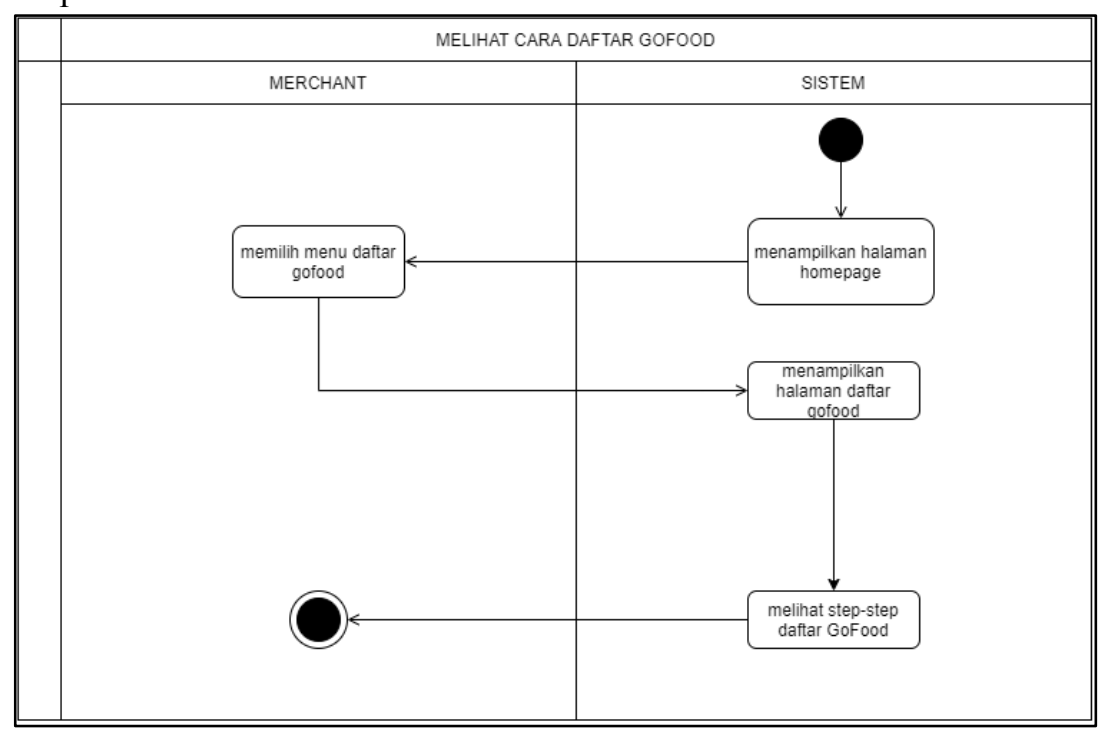

Gambar 4. Activity diagram melihat cara promo

Gambar 4 merupakan activity diagram dari proses melihat cara promo sebagai merchant yang dimulai dari sistem menampilkan halaman homepage. Kemudian pengguna memilih menu navigasi cara promo. Setelah itu, sistem mengarahkan untuk menampilkan halaman cara promo.

\subsection{Implementasi Sistem}

\subsubsection{Implementasi Interface Sistem}

Berikut adalah implementasi tampilan (interface) program yang dibuat pada kegiatan pengabdian ini :

a. Halaman Utama 


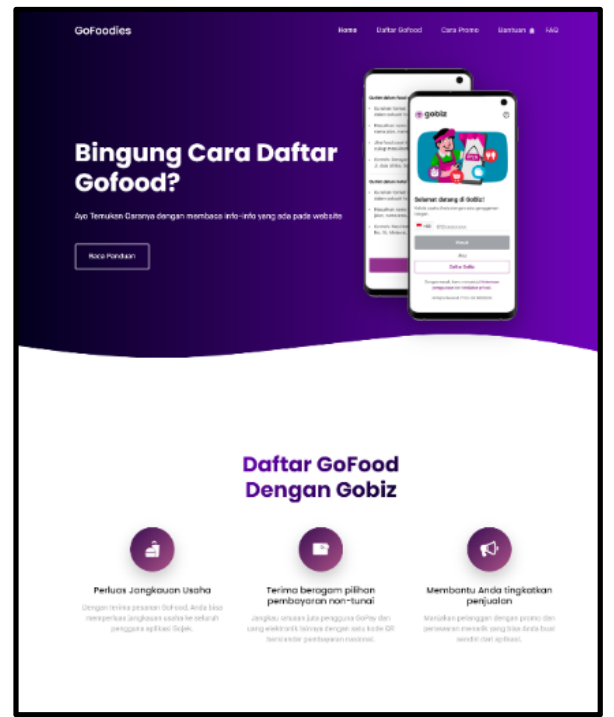

Gambar 5. Halaman utama

Pada Gambar 5 merupakan implementasi dari halaman homepage yang muncul pertama kali ketika merchant mengakses website.

b. Halaman Daftar Gofood

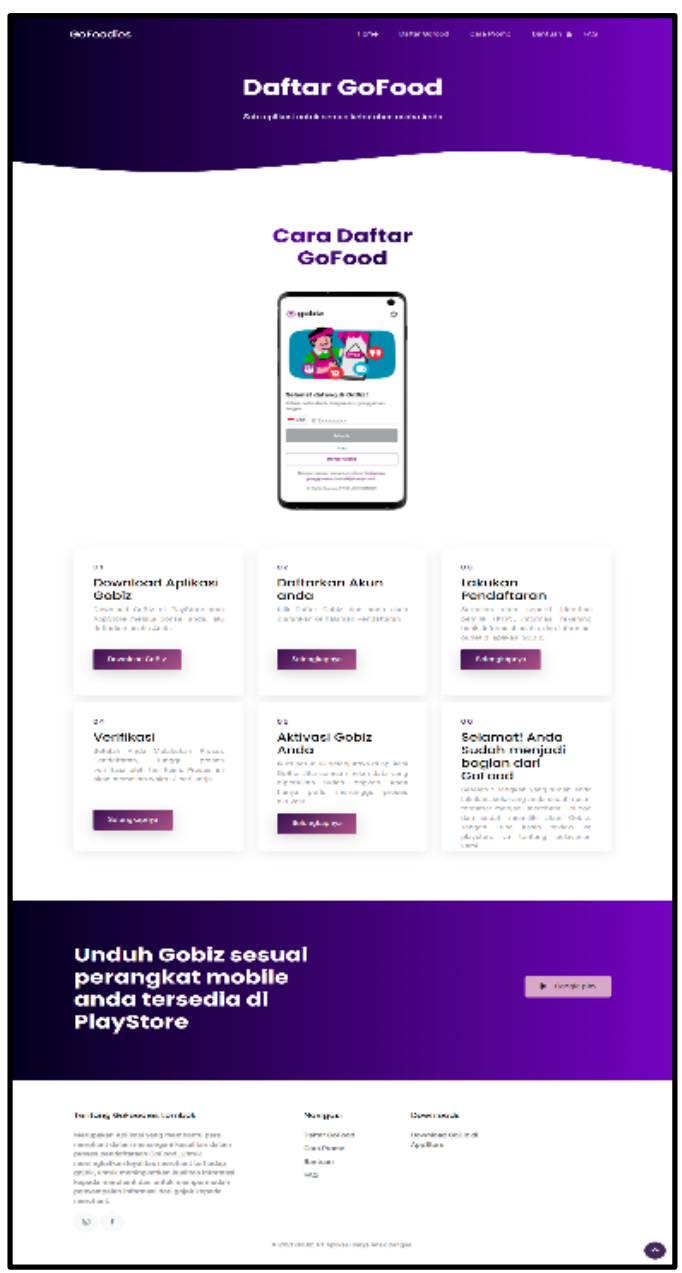

Gambar 6. Halaman Daftar Gofood

Pada Gambar 6 merupakan implementasi dari halaman daftar Gofood yang digunakan bagi merchant untuk mengetahui info cara-cara mendaftar gofood. 
c. Halaman Cara Promo

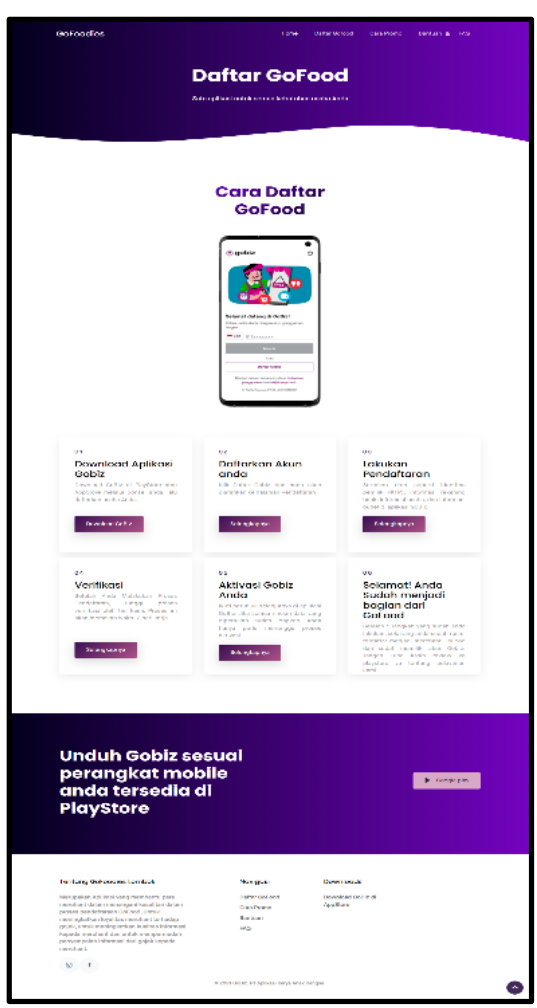

Gambar 7. Halaman Cara promo

Pada Gambar 7 merupakan implementasi dari halaman cara promo yang digunakan bagi merchant untuk mengetahui info cara-cara melakukan promosi.

d. Halaman Artikel Bantuan

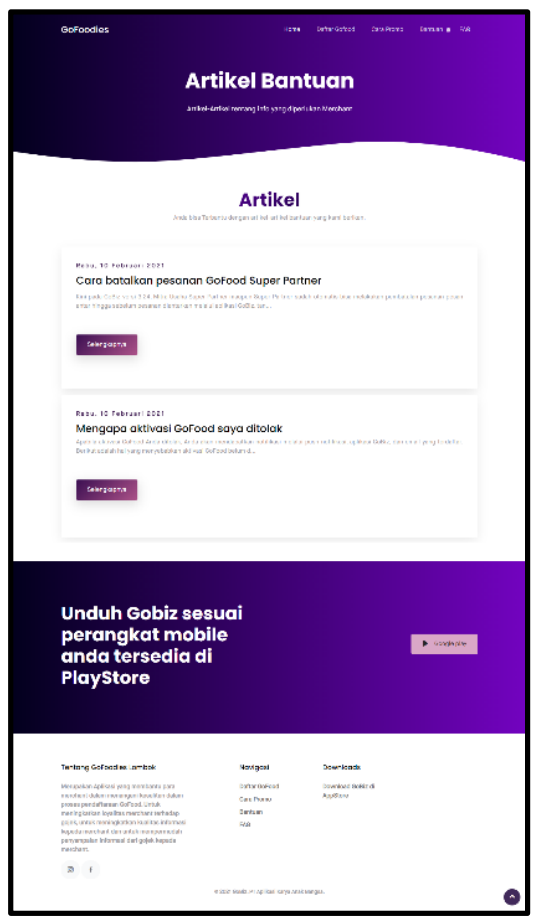

Gambar 8. Halaman Artikel Bantuan

Pada Gambar 8 merupakan implementasi dari halaman artikel bantuan yang digunakan bagi merchant untuk mengetahui info artikel bantuan untuk masalah merchant. 
e. Halaman Kontak Kami

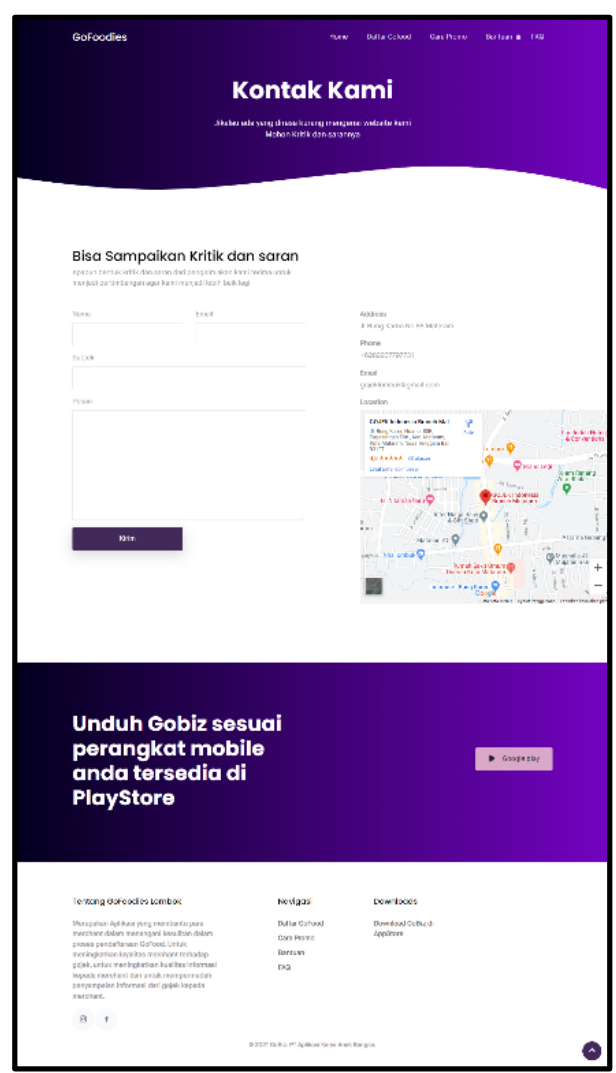

Gambar 9. Halaman Kontak Kami

Pada Gambar 9 merupakan implementasi dari halaman kontak kami yang digunakan bagi merchant untuk dapat pelayanan kontak bila ada pertanyaan maupun kritik dan saran.

\section{f. Halaman FAQ}

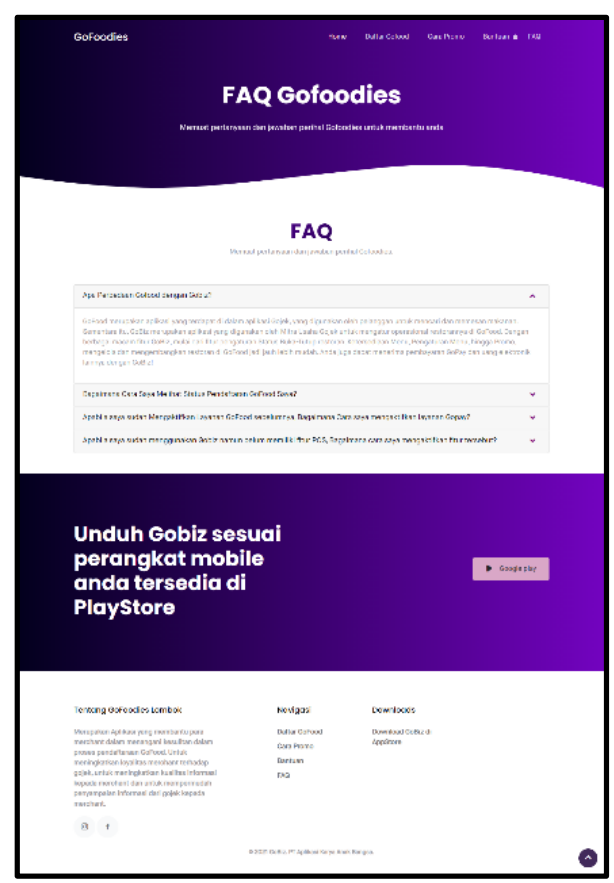

Gambar 10. Halaman FAQ

Pada Gambar 10 merupakan implementasi dari halaman FAQ yang digunakan bagi merchant untuk mengetahui info FAQ untuk masalah merchant. 


\section{Hasil dan PeMbahasan}

Pada pengabdian masyarakat ini dilakukan pengimplementasian sistem dengan tampilan seperti yang telah ditunjukan pada bagian 3. Kemudian berdasarkan implementasi sistem tersebut dilakukan pengujian sistem. Pengujian dengan menggunakan kuesioner dilakukan dengan cara mencari responden yang merupakan pegawai Gojek Indonesia Cabang Lombok untuk melakukan uji coba sistem dan menjawab pernyataan pada kuesioner yang diberikan.

Parameter pengujian yang digunakan pada metode ini adalah :

a. Apakah tampilan Interface pada web gofoodies menarik dan mudah dimengerti?

b. Fitur-fitur yang ada sudah lengkap dan berjalan sesuai fungsionalitasnya?

c. Apakah kualitas informasi kepada merchant jadi lebih baik dan efektif?

d. Apakah sistem mudah dioperasikan?

e. Apakah sistem dapat memudahkan pekerjaan divisi merchant?

Responden akan diberikan pilihan jawaban dari pertanyaan-pertanyaan di atas, yaitu :
a. SS = Sangat Setuju
b. $\mathrm{S}=$ Setuju
c. $\mathrm{C}=$ Cukup
d. $\mathrm{TS}=$ Tidak Setuju
e. STS $=$ Sangat Tidak Setuju

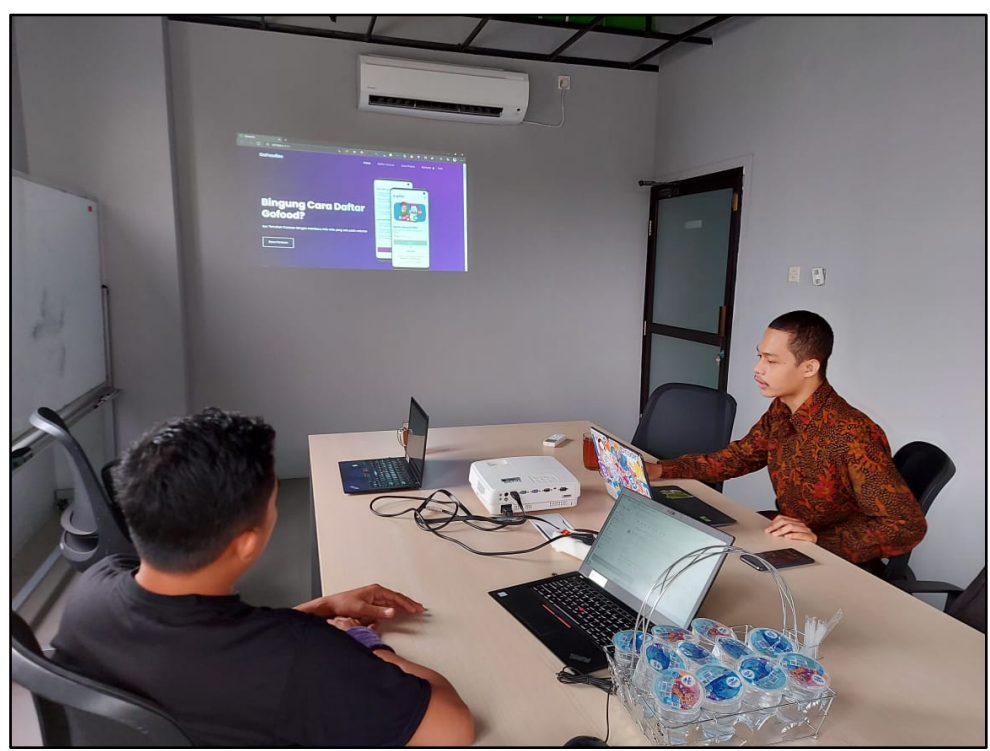

Gambar 11. Presentasi pengujian sistem

Hasil rekapitulasi jawaban responden dihitung dari jawaban berdasarkan pengisian kuesioner dari masingmasing pernyataan. Berikut pada gambar 12. merupakan grafik persentase jawaban rata-rata hasil pengujian dari 5 responden dari divisi merchant dan divisi marketing:

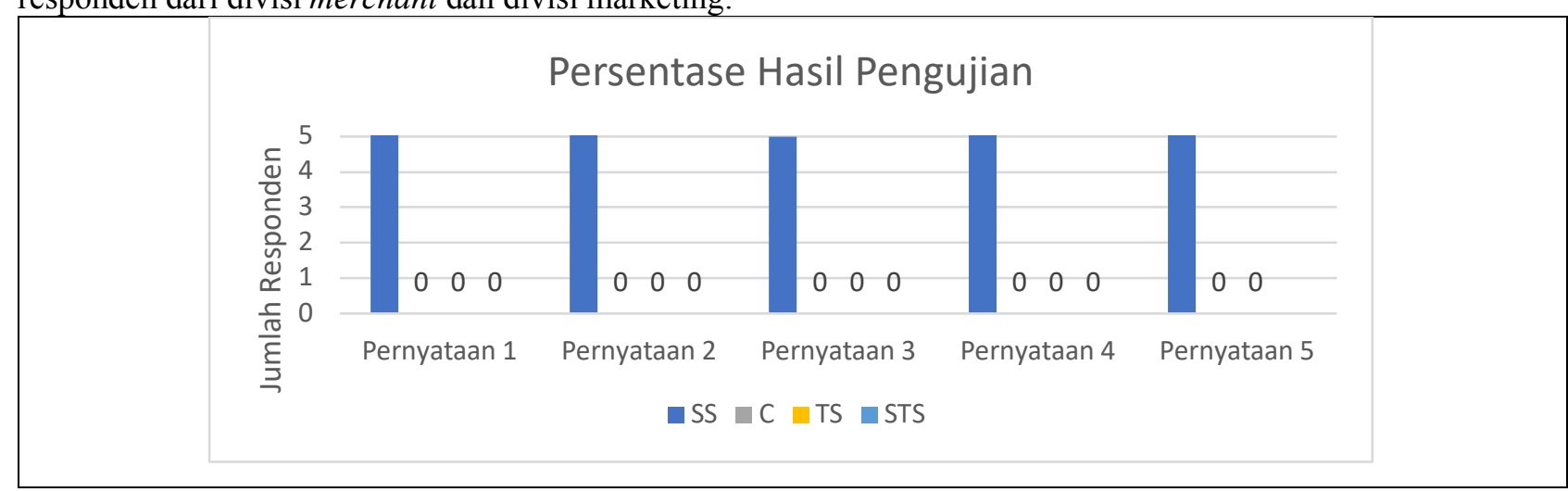

Gambar 12. Persentase hasil pengujian 
Pada Gambar 12 merupakan hasil persentase pengujian dari kuesioner yang diberikan : untuk pertanyaan 1 nilai Sangat Setuju diberikan oleh 5 orang responden, untuk pertanyaan 2 nilai Sangat Setuju diberikan oleh 5 orang responden, untuk pertanyaan 3 nilai Sangat Setuju diberikan oleh 5 orang responden, untuk pertanyaan 4 nilai Sangat Setuju diberikan oleh 5 orang responden, dan untuk pertanyaan 5 nilai Sangat Setuju diberikan oleh 5 orang responden. Sehingga berdasarkan jawaban responden tersebut dapat disimpulkan bahwa responden setuju dengan sistem yang telah dibangun.

\section{KESIMPULAN DAN SARAN}

\subsection{Kesimpulan}

Berdasarkan pengabdian masyarakat yang dilakukan di Gojek Indonesia Cabang Lombok berupa pembuatan Sistem Informasi Gofoodies Lombok berbasis website dengan menggunakan framework Laravel dan Bootstrap, maka didapatkan kesimpulan sebagai berikut :

1. Sistem Informasi Gofoodies Lombok berbasis website yang dibangun memiliki layanan yang dibutuhkan oleh merchant seperti bagaimana cara daftar Gofood, cara melakukan promo dan memberikan layanan bantuanbantuan untuk merchant sehingga dapat meningkatkan loyalitas merchant terhadap Gojek. Selain itu juga dapat membuat masyarakat mengetahui informasi tentang cara menjadi seorang merchant.

2. Rancangan Sistem Informasi Gofoodies Lombok berbasis website dibuat berdasarkan hasil analisa kualitas penyajian informasi terhadap merchant, sehingga dengan adanya rancangan sistem ini dapat meningkatkan kualitas informasi kepada merchant.

3. Sistem Informasi Gofoodies Lombok berbasis website yang dibangun memiliki layanan yang dibutuhkan oleh merchant seperti memberikan layanan untuk memberikan kritik dan saran dan memberikan layanan bantuanbantuan berupa artikel dan FAQ untuk merchant sehingga dapat meningkatkan keterikatan merchant terhadap Gojek.

\subsection{Saran}

Adapun saran yang dapat diberikan penulis agar Sistem Informasi Gofoodies Lombok berbasis website ini menjadi lebih baik di masa yang akan datang adalah sebagai berikut:

1. Perlunya dilakukan analisa dan perancangan lebih mendalam terhadap kebutuhan merchant guna membangun sistem yang sesuai dengan kebutuhan merchant Gojek dalam waktu yang lebih singkat.

2. Dalam pengembangan selanjutnya, diharapkan Sistem Informasi Gofoodies Lombok berbasis website dapat menjadi lebih kompleks dalam menu maupun fungsinya agar dapat dimanfaatkan lebih maksimal.

\section{UCAPAN TERIMA KASIH}

Ucapan terima kasih kepada instansi Gojek Indonesia cabang Lombok khususnya kepada bapak divisi merchant dan divisi marketing yang telah memberikan kesempatan melakukan kegiatan penelitian dan pengabdian masyarakat. Rekanrekan divisi merchant dan marketing yang memberikan data dan informasi untuk dijadikan sebagai bahan dasar untuk pembuatan sistem. Serta kepada keluarga dan teman-teman yang membantu penulis dalam melaksanakan penelitian dan pengabdian ini

\section{DAFTAR PUSTAKA}

[1] Hendini, Ade. 2016. "Pemodelan UML Sistem Informasi Monitoring Penjualan Dan Stok Barang (Studi Kasus: Distro Zhezha Pontianak).” Jurnal Khatulistiwa Informatika IV(2): 107-16.

[2] Hutahaean, Jeperson. 2015. Konsep Sistem Informasi. Sleman: deepublish.

[3] Pamungkas, Canggih Aji. 2017. Pengantar Dan Implementasi Basis Data. Sleman: deepublish.

[4] Sumiati, S.E. Anjarwani, M.A. Albar. 2018. "Rancang Bangun Sistem Informasi Pengelolaan Surat dan Kearsipan pada Sekertariat Daerah Provinsi NTB berbasis WEB.” J-COSINE 1(2): 9-11.

[5] Sutopo, Priyo, Dedi Cahyadi, and Zainal Arifin. 2016. "Sistem Informasi Eksekutif Sebaran Penjualan Kendaraan Bermotor Roda 2 Di Kalimantan Timur Berbasis Web.” 11(1).

[6] H. Hidayat, Cara Instan Menguasai Pemrograman Website Secara Otodidak. Jakarta Barat: Agogos Publishing, 2016.

[7] Rozi A. Zaenal \& Community Smit Dev, 2015. “Bootstrap Design Framework”, Jakarta: PT Elex Media Komputindo. 